\title{
The clinical and genetic factors for predicting the response to inhaled corticosteroids
}

\author{
Hiroyuki Nagase ${ }^{1 *}$, Naomi Tsurikisawa ${ }^{2}$, Asae Kamiyama' ${ }^{1}$ Eiko Matsui ${ }^{3}$, Naomi Kondo ${ }^{3}$, Kazuo Akiyama ${ }^{2}$, Ken Ohta ${ }^{4}$ \\ From EAACI International Severe Asthma Forum (ISAF 2012) \\ Gothenburg, Sweden. 11-13 October 2012
}

\section{Background}

It has been reported that a part of asthma patients does not respond well to inhaled corticosteroids (ICS) and the benefit by long term treatment by high-dose ICS is limited in such patients. But the clinical or genetic factors for predicting ICS response have not been fully established especially in adults. The aim of this study is to establish the factor for predicting the response to ICS treatment.

\section{Method}

Patients treated only by ICS for more than 6 months were enrolled and classified into responder group ( $\mathrm{R}$ group, $\mathrm{n}=30$ ) if FEV1 improvement $\geq 5 \%$ and nonresponder group (NR group, $\mathrm{n}=40$, FEV1 improvement $<5 \%)$. The relationship between ICS response and pretreatment clinical indices and 21 single nucleotide polymorphism (SNP) were retrospectively analyzed.

\section{Results}

In R group, peripheral blood eosinophil \% (R: NR = 7.5: 4.3\%) and serum total IgE level (550.4: $497.1 \mathrm{U} / \mathrm{ml}$ ) was significantly higher as compared to NR group. R group also showed significantly lower \%VC (97.5: 114.8\%), \% FEV1.0 (77.9: 101.3\%), FEV1.0\% (67.5: 76.4\%) and higher bronchial hyperresponsiveness. Bronchial reversibility test was available in 30 patients (R: $n=11, N R: n=19)$ and reversibility was significantly higher in R group (15.9: 5.4\%). By logistic multivariate analysis for those 30 patients, bronchial reversibility was significantly related to ICS response. SNP in IFN- $\gamma$ R1 L467P was also related to ICS response. Post/Pre FEV1 ratio was significantly higher in homo/ hetero group as compared to wild group (140.2 v.s 108.8\%).

${ }^{1}$ Teikyo University School of Medicine, Department of Medicine, Japan Full list of author information is available at the end of the article

\section{Conclusion}

Pre-treatment bronchial reversibility was identified as a prediction factor for ICS response. It has been reported that SNP in IFN- $\gamma \mathrm{R}$ is associated with allergic diseases and serum IgE level and the SNP might be potentially related to ICS response.

\section{Author details}

${ }^{1}$ Teikyo University School of Medicine, Department of Medicine, Japan. ${ }^{2}$ National Hospital Organization Sagamihara National Hospital, Clinical Research Center, Japan. ${ }^{3}$ Gifu University Graduate School of Medicine, Department of Pediatrics, Japan. ${ }^{4}$ National Hospital Organization Tokyo National Hospital, Department of Respiratory Diseases, Japan.

Published: 3 May 2013

doi:10.1186/2045-7022-3-S1-P15

Cite this article as: Nagase et al.: The clinical and genetic factors for predicting the response to inhaled corticosteroids. Clinical and Translational Allergy 2013 3(Suppl 1):P15.

Submit your next manuscript to BioMed Central and take full advantage of:

- Convenient online submission

- Thorough peer review

- No space constraints or color figure charges

- Immediate publication on acceptance

- Inclusion in PubMed, CAS, Scopus and Google Scholar

- Research which is freely available for redistribution 